\title{
Halal destinations in Asia: A SWOT analysis
}

\author{
A. Tohe*, H. Pratikto \& Kholisin \\ Universitas Negeri Malang, Malang, Indonesia \\ R.B. Atan \\ Universiti Putra Malaysia
}

\begin{abstract}
This research is aimed at investigating the current state of halal destinations in four Asian countries: Indonesia, Malaysia, Thailand, and Japan. Assessment of destinations in each country was conducted using a SWOT analysis, before setting up a comparison to identify their competitive advantages and determining the relative correlation between the perceived readiness of destinations with the inbound tourist arrival. Features of assessment were based on the conceptual framework developed by COMCEC 2016, known as Muslim-Friendly Tourism (MFT), consisting of Six Faith-based Needs, Demand Side Key Themes (reasons and motivation for travel) and Supply Side Key Themes (travel \& hospitality services and facilities). The results showed that three variables had been important in shaping the decision that potential inbound Muslim tourists made to visit a halal destination: religious and cultural affinity, affordability and visa-freedom. The more visible the correlation that a destination had with these three, the more likely that it received more visits. Furthermore, the first two factors were found to compensate for the alleged weaknesses found in a halal destination, as long as it provided basic halal needs.
\end{abstract}

Keywords: halal tourism, Asian countries, MFT, SWOT Analysis

\section{INTRODUCTION}

Halal tourism is a new phenomenon expanding from the ever-growing halal industry (Samori et al. 2015). The increasing demand for tourism among Muslims has run parallel with the growth of the Muslim population worldwide (Henderson 2016), in addition to the improved affluence that allowed for greater consumption and expenditure (Fischer 2011). Catering to the needs of Muslims, halal tourism is highly lucrative, showing an annual growth of 5\%, slightly exceeding the growth of general tourism at $4 \%$. Predicted to be the largest religious population in some coming decades, it is the Muslims who primarily funded and moved this new model of business (Pietro \& Secinaro 2019). Furthermore, halal tourism had demonstrated the propensity to expand over time. As such, halal tourism had inspired many service providers, in both Muslim and non-Muslim countries, to build new hotels, open up new attractions, start new restaurants, and offer new travel packages (Muhamad et al. 2019).

Halal tourism is growing because, in addition to Muslim countries such as Indonesia and Malaysia, non-Muslim countries have also participated in providing halal services and destinations (Muhamad et al. 2019). In Asia, countries such as Japan and Thailand had taken advantage of this opportunity by offering Muslim-friendly facilities and services to inbound Muslim visitors. Halal food was available in many places in the two countries: on flight, in the airports, or some restaurants downtown, just as prayer facilities were more easily found in public places, although not adequately enough to satisfy the needs of the Muslim tourists visiting (Hamid et al. 2018).

*Corresponding author 
Tourism had contributed quite significantly to Indonesia's economic growth (Jaelani 2017), especially when the national economy was facing a global crisis by showing an increase in the terms of the export of goods and services (Widagdyo 2015). GMTI (2019) ranked Indonesia as the most favorable halal destination among members of the Organization of Islamic Cooperation (OIC) countries. Indonesia had the best opportunity to lead the halal tourism industry because it might be the country best able to provide what the Muslim tourists need, not only in terms of practicing their religion while traveling, but also in terms of a sense of security, safety, and familiarity. For Middle Eastern Muslim tourists, in particular, Indonesia could offer rich natural and cultural tourism sites that are markedly different from the ones found in their place of origin (Mubarok \& Imam 2020). The Muslim-friendly ambience that Indonesia offered, due to the religious and cultural affinity and the wide availability of halal services and facilities, were the most attractive factors for inbound Muslim tourists to visit (OIC 2017), in addition to its affordability that potentially improved tourists' purchasing power.

Furthermore, the government's strong commitment to support halal tourism in the country hadbeen well attested to (OIC 2017). In 2015, the Ministry of Tourism and Creative Economy of Indonesia launched "Muslim Guides," in addition to forming a special committee that oversaw the development of halal tourism and its promotion. The government had also organized several campaigns by orchestrating social media influencers to portray Indonesia as a Muslim-friendly destination. It had chosen, based on 80 parameters, some tourism regions - namely Lombok, West Sumatra, and Aceh-as competitive destinations (OIC 2017). Moreover, Indonesia had been actively involved in some international halal tourism events and forums. These and other governmental efforts had made Indonesia the most favorable destination (GMTI 2019).

Malaysia has been consistently one of the top ranked destinations worldwide in halal tourism. The Master Card Crescent Rating had positioned Malaysia on top among OIC members in terms of the friendliness of its halal facilities and services (Hamid et al. 2018). GMTI 2019 also put Malaysia, along with Indonesia, as the most favorable halal destinations among OIC countries. Not only had tourism been significant in its economy, but it had also demonstrated a constant increase in supporting Malaysia's state revenue over time, in addition to providing opportunities for new jobs (Hamid et al. 2018).

Similar to Indonesia, Malaysia had benefited from its status as a Muslim majority country, despite some deficiencies in its handling of halal tourism. While tourism in Malaysia was more Western-inspired and did not pay special attention to Muslim tourists' needs, but its status as a Muslim country had created some guarantee for Muslim travelers that they would not have any difficulties in finding Muslim-friendly facilities during their visit. However, on a larger scale, in places where tourists come in huge groups, this lack of accommodation could present a challenge to cater to the needs of tourists, especially in regard to halal food (Hamid et al. 2018).

In the spirit of capturing the booming market, Japan had responded to the needs of Muslim tourists by training hospitality staff through a "Muslim-Friendly Project" (Battour 2018), which aimed at increasing staff's understanding of Muslims' needs and concerns. All efforts that Japan made to restructure its tourism to be more Muslim-friendly had made the country as one of the most popular destinations for Muslim travelers (Hariani 2017). Of non-OIC countries, Japan ranked second as a favored destination (GMTI 2019), showing some improvement from 2017 and even replacing Thailand that had been in that second position in previous years. Japan witnessed an almost double increase of inbound Muslim visitors between 2010 and 2015 (Henderson 2016). Such a significant increase could have been the result of a combination of factors, such as the ease of air connectivity and visa requirements, in addition to intensive campaigns and the devaluation of the Yen that allowed for more affordability (Henderson 2016).

Regardless, Japan retained some weaknesses as a halal destination, the most crucial of which was the lack of understanding of Islam due to its thin interaction with Muslims (Adidaya 2016). For a long time, Japan had been a monocultural society, with a tiny Muslim minority who had been almost completely ignored. Furthermore, the living cost in Japan was relatively expensive. The raw materials for halal foods were scarce (Yusof \& Shutto 2014). Even products declared halal did not always provide a detailed description of the ingredients. The cost for halal certification was high, so was the investment in halal infrastructure. Staff had limited communication skills, largely using Japanese (Henderson 2016). 
Thailand is another non-Muslim Asian country that had attempted to take advantage of the economic opportunity offered by halal tourism. It had taken a number of responsive steps to accommodate the needs of Muslim travelers, including the launching of a multilingual Muslimfriendly application, available for Android and IOS, to help Muslim visitors find halal restaurants and hotels, mosques and halal tours, as well as providing travel news and a guidebook (Battour 2018). Thailand established the Al-Meroz Hotel with fully halal facilities and services (Mohsin et al. 2017), followed by four other halal hotels that were launched afterward. More halal hotels could be established in the future (Chandra 2014), especially considering the increased visit of Muslim travelers to the country (Razalli et al. 2012), and the fact that the increase of halal hotels had, in fact, attracted more Muslim tourists (Samori \& Rahman 2015).

Thailand was considered one of favorite destinations for Muslims (Rashid et al. 2019), and had welcome visitors from the Islamic world for many decades (Nurdiansyah 2018). The satisfaction level of Muslim travelers who had visited Thailand was relatively high, especially in terms of the availability of halal foods (Sriprasert et al. 2014). Other factors cited to have contributed to the satisfaction of Muslim travelers included security, safety and the destination's socio-cultural attractions. Thailand's tourism strengths were that its people were known to be friendly, its exotic beaches, and its medical services (Wong et al. 2014). Abundant access to halal food had influenced the Muslim travelers to stay longer, intend to return or recommend the destination to others (Mannaa 2019). Thailand had undertaken "gastrodiplomacy" by promoting Thai food to attract more foreign travelers, including Muslims (Muangasame \& Park 2019). But Thailand had to face the problem of a shortage of skilled staff (Waehama et al. 2018), especially Muslim staff for halal hotels (Oktadiana et al. 2016). Finding such needed staff was a challenge given the small size of Thailand's Muslim population, and it had to find them overseas which was rather costly (Waehama et al. 2018).

\section{METHODS}

This research surveyed as many published studies on halal tourism as possible as it developed in the four Asian countries. The focus was to identify how the six faith-based needs of Muslim travelers as defined by COMCEC 2016, which were halal food, Salaah (Prayer), water usage friendly toilets, Ramadhan services and facilities, facilities with no non-halal activities and recreational facilities with privacy, were satisfied in halal destinations in each country. SWOT analysis was employed to determine the areas of strengths, weakness, opportunities, and threats that each country possesses with regard to its halal destinations, underlining key factors that supported its popularity or the lack thereof.

\section{RESULTS AND DISCUSSION}

The strength of Indonesia's halal destinations lay in that they all catered to most Muslim tourists' needs with an easy access, and the country had received a huge arrival of Muslim tourists with leisure motivation. Inconsistent halal certification, the presence of non-halal products and activities, the low quality of infrastructure to destinations, unskilled staff, and the relatively low arrival of tourists with business and medical/healthcare motivation posed as weaknesses. Opportunities were open in terms of providing improved Ramadan services, locally diverse and unique local experiences and attractions with privacy. The greatest threat was that Indonesia faced fierce competition from Malaysia, which had many similarities but was able to offer better professional services and a more comprehensive halal certification.

While Malaysia was strong in providing easily accessible solutions to tourists' needs and in terms of a high arrival of tourists with all motivations, it had some weaknesses with regard to the presence of non-halal products and activities in the destinations, in addition to the fact that tourism remained largely concentrated in big cities with little privacy. Opportunities abounded in terms of developing business and medical/healthcare tourism and more consistent halal certification for hotel services. 
The greatest threats came from Indonesia because it gave more access to rural destinations and from Thailand because it provided robust medical/healthcare tourism at a competitive cost.

Thailand had an abundance of halal foods and prayer facilities and a high arrival of medi$\mathrm{cal} /$ healthcare tourists but remained restricted in the urban areas. In general, the halal destinations in the country suffered from scarce and poorly distributed halal facilities and services, especially in rural areas. Thailand, however, had a great opportunity to improve halal hotel services and to push further the initiatives for halal MICE (Uansaard 2018). The greatest threat to Thailand's halal tourism came from three other countries that had a competitive advantage in almost all aspects.

Japan started to provide more adequate halal facilities and services, although mostly in main cities and in a much lower availability than the other three countries. But the opportunity for further improvements was open, as Japan witnessed a steadily increasing number of inbound Muslim tourists because of the increased promotion of the combination of technological advancement and cultural heritage using social media. The greatest threat was the fact that Japan had to compete fiercely with three other countries that had proved to be more ready, more welcoming and much cheaper.

\subsection{Religious and cultural affinity}

Cultural and religious affinity proved to be one of the strongest motivating reason $\mathrm{s}$ for inbound Muslim tourists to visit a halal destination in a country. This had been the case with Indonesia and Malaysia, which had received the highest arrival of the four Asian countries studied. The level of inbound tourists' arrival was an empirical yardstick for the strength of any destination (Batabyal \& Mukherjee 2018). Was the handling of halal tourism in Indonesia and Malaysia perfect? The answer was "not really." There were some obvious weaknesses at any level, but the perception that the two countries were Muslim countries, or at least Muslim-friendly countries, had been taken for granted, and therefore allowed the ignoring of perceived weaknesses. Halal foods, prayer facilities, and toilets with water were everywhere, from the airports to destinations. Finding a restaurant to eat at or a hotel to stay at that offered no alcohol was not necessarily challenging. Modesty of dress code was more common in public places, as this had not been encouraged or prohibited by Islam. Foreign Muslim tourists felt at home when visiting Indonesia and Malaysia, precisely due the fact that they shared the same religious beliefs, which not only conferred a sense of familiarity and even brotherhood, but also of security and safety. These feelings of familiarity, security and safety were among the most important factors foreigners sought when they were in a new country. In short, the inbound Muslim tourists visiting Indonesia and Malaysia were almost worry-free. The worst that they might find may simply be considered "inconveniences," which could actually enrich the experience being in a foreign land.

The situation would be slightly or even largely different if Muslim tourists visited a non-Muslim or minority Muslim country, such as Japan or Thailand. The host society had different customs and traditions dictated partly by their religious beliefs. In japan, for instance, there was a cultural element, called Nomikai, which refers to the possible limitation with which foreigners were unable to socialize as freely with the local population and get involved in their activities (Adidaya 2016). To some extent, a sense of unfamiliarity was accentuated, not only on the part of the visiting tourists but also on the receiving hosts. The two sides could face some awkward situations of how to behave with one-another. Foods were unfamiliar, and raised the question whether they were religiously edible. Prayer facilities were hard to find, toilets with water were similarly rare, as the host society did not have to use water, but papers or tissues, for cleaning. To add to this, the potential prejudices that might have circulated between people from different religious or ethnic backgrounds, such as Islamophobia, which also often came up in the news. In a nutshell, visiting non-Muslim countries, with sets of social and cultural differences, Muslim tourists faced not only some challenges that could make them constantly conscious about everything, including those deficiencies in services that they might readily ignore or forgive in Muslim countries, but also some risks that potentially jeopardize their expectation of gaining meaningful experience and joy during their stay. Thus, religious and cultural affinity was one of the most important factors that had not only shaped the 
decision to visit in the first place but also the subsequent experience of Muslims when undertaking halal tourism

\subsection{Affordability}

Another reason for the high arrival of inbound Muslim tourists was affordability. Of the four countries being studied, Malaysia and Indonesia shared first place among the OIC countries, while Thailand and Japan were ranked second and third among non-OIC countries (GMTI 2019). To some extent, the level of visits was closely correlated with the destinations' relative affordability. Of the four, Indonesia was the most affordable and Japan was the costliest, with Malaysia and Japan being between the two ends of the spectrum. Furthermore, affordability might have compensated for some weaknesses found in destinations, as long they provided the basic halal needs of Muslim travelers, such as halal foods. Economically, the Muslim tourists would be happy to receive more with less money, and they could get just this by visiting Indonesia and Malaysia.

The same affordability thesis also applied in Thailand with regard to medical/healthcare tourism. Thailand had been known for its leading medical treatment, not only in Asia but also globally. Apart from the fact that it had many internationally accredited hospitals and medical personnel with reputable licenses, Thailand's leadership in medical/healthcare tourism had been credited to the fact that it charged much less for the same treatment than if it was done in the West, for instance. Likewise, after the devaluation of the Yen, Japan had witnessed an increase of inbound tourists and had demonstrated a steady rise ever since

\subsection{Visa relaxation}

As ordinary as it might appear, the visa relaxation for inbound travelers to enter a country was of significance. Not only did it reduce the financial burden that the prospective tourists could have initially take on, but it also removed the inconvenience that they should go through with the administrative process. In fact, visa freedom policies had increased human mobility (Freier \& Holloway 2018), and it was a part of regional alliances and the formation of regional blocs (Czaika et al. 2018). Thus, the entry visa not being required in a number of countries was an expression of alliances that they forged in order to be mutually advantaged and reciprocally benefited from the booming halal industry.

The fact that these four countries had implemented a visa-free entry for their citizens to visit was a sign that they were in an equal position to benefit each other. This policy had been productive in motivating people, including Muslims, to travel across borders. Halal tourism had also been impacted by this visa freedom as more inbound tourist arrival was continually increasing in the four countries. With this ease, prospective tourists needed only to pay for a return flight ticket, and to prepare some amount to spend during their stay in the destination country, without bothering to make an arrangement for appointments with and visit to a foreign consulate or embassy

\section{CONCLUSION}

The results of a SWOT analysis of halal destinations in the four Asian countries suggested three variables as key factors that had shaped tourists' decision to visit and their subsequent experience in destinations, namely religious and cultural affinity, affordability, and visa freedom. The relative correlation that each destination had with the three variables determined its priority by the prospective tourists to be a chosen destination. The more conspicuous the relation that a halal destination had with the three variables, the more likely that it received more visits by inbound Muslim tourists. In this respect, Indonesia and Malaysia had been the most popular halal destinations. Furthermore, it is also suggested, religious and cultural affinity and affordability had compensated for the perceived weaknesses found in destinations, as long as they provided basic halal needs. 


\section{REFERENCES}

Adidaya, Y. A., 2016. Halal in Japan: History, Issues and Problems. Oslo: Department of Culture Studies and Oriental Languages, University of Oslo.

Batabyal, D. \& Mukherjee, S. K., 2018. Determinants of Tourist Visits in Destination Development: An Empirical Analysis of Sikkim. In: Tourism Marketing: A Strategic Approach. Oakville, CA \& Waretown, NJ: Apple Academic Press Inc, pp. 11-24.

Battour, M., 2018. Muslim Travel Behavior in Halal Tourism. The Creative Commons Attribution License.

Chandra, G. R., 2014. Halal Tourism: A New Gold Mine for Tourism. International Journal of Business Management \& Research, 4(6), pp. 45-62.

Czaika, M., De Hass, H. \& Villares-Varela, M., 2018. The Global Evolution of Travel Visa Regimes. Population and Development Review, 44(3), pp. 589-622.

Fischer, J., 2011. The halal frontier: Muslim consumers in a globalised market. New York, NY: Palgrave Macmillan.

Freier, L. F. \& Holloway, K., 2018. The Impact of Tourist Visas on Intercontinental South-South Migration: Ecuador's Policy of “Open Doors” as a Quasi-Experiment. International Migration Review, pp. 1-38.

GMTI, 2019. Global Muslim Travel Index, s.1., Mastercard-CrescentRating.

Hamid, S. H. A., Aziz, Y. A., Rahman, A. A. \& Ali, M. H., 2018. Implementing Big Scale Halal Tourism in Malaysia. International Journal of Academic Research in Business and Social Sciences, 8(16), p. 304-318.

Hariani, D., 2017. Halal Japanese Culinary as Attraction for Muslim Travellers to Visit Japan. s.1., Advances in Economics, Business and Management Research, pp. 174-176.

Henderson, J. C., 2016. Muslim travellers, tourism industry responses and the case of Japan. Tourism Recreation Research.

Jaelani, A., 2017. Industri Wisata Halal di Indonesia: Potensi dan prospek. Munich Personal RePec Archive, No. 76237.

Mannaa, M. T., 2019. Halal Food in The Tourist Destination and Its Importance for Muslim Travellers. Current Issues in Tourism.

Mohsin, A., Ramli, N. \& Alkhulayfi, B. A., 2017. Halal tourism: Emerging opportunities. Tourism Management Perspectives, Volume 19, pp. 137-143.

Muangasame, K. \& Park, E., 2019. Food Tourism, Policy and Sustainability: Behind the Popularity of Thai Food. In: Food Tourism in Asia: Perspectives on Asian Tourism. Singapore: Springer.

Mubarok, F. K. \& Imam, M. K., 2020. Halal Industry in Indonesia: Challenges and Opportunities. Journal of Digital Marketing and Halal Industry, 2(1), pp. 55-64.

Muhamad, N. S., Sulaiman, S., Adham, K. A. \& Said, M. F., 2019. Halal Tourism: Literature Synthesis and Direction for Future Research. Pertanika J. Soc. Sci. \& Hum, 27(1), pp. 729-745.

Newsroom, T., 2020. https://www.tatnews.org

Newsroom, T., 2020. TAT Governor urges industry patience and solidarity to overcome the COVID-19 crisis.

Nurdiansyah, A., 2018. Halal Certification and Its Impact on Tourism in Southeast Asia: A Case Study Halal Tourism in Thailand. s.1., KnE Social Sciences, pp. 26-34.

OIC, 2017. Strategic Roadmap for Development of Islamic Tourism in OIC Member Countries, s.1., The Statistical, Economic and Social Research and Training Centre for Islamic Countries (SESRIC).

Oktadiana, H., Pearce, P. L. \& Chon, K., 2016. Muslim Travellers' Needs: What Don't We Know?. Tourism Management Perspectives, Volume 20, pp. 124-130.

Osman, N., 2019. Halal holidays: Sun, sea and seclusion appeal to women, s.1., s.n.

Pietro, B. P. \& Secinaro, S., 2019. The Halal Tourism: A Business Model Opportunity. In: Islamic Tourism: Management of Travel Destinations. Oxfordshire: CABI, pp. 192-200.

Rashid, N. R. N. A., Akbar, Y. A. A., Laidin, J. \& Muhamad, W. S. A. W., 2019. Factors Influencing Muslim Tourists Satisfaction Travelling to Non-Muslim Countries. In: Contemporary Management and Science Issues in the Halal Industry. Singapore: Springer, pp. 139-150.

Razalli, M. R., Abdullah, S. \& Yusoff, R. Z., 2012. Is Halal Certification Process “Green”?. The Asian Journal of Technology Management, 5(1), pp. 33-41.

Samori, Z. \& Rahman, F. A., 2015. Establishing shariah compliant hotels in Malaysia: Identifying Opportunities, Exploring Challenges. West East Journal of Social Sciences, 2(2), pp. 95-108.

Samori, Z., Salleh, N. Z. M. \& Khalid, M. M., 2015. Current trends on Halal tourism: Cases on selected Asian countries. Tourism Management Perspectives.

Sriprasert, P., Chainin, O. \& Rahman, H. A., 2014. Understanding Behavior and Needs of Halal Tourism in Andaman Gulf of Thailand: A Case of Asian Muslim. Journal of Advanced Management Science, 2(3), pp. 216-219. 
Uansaard, S., 2018. Creating the awareness of halal MICE tourism business in Chiang Mai. Int. J. Tourism Policy, 8(3).

Waehama, W., Alam, M., Hayeemad, M. \& Waehama, W., 2018. Challenges and Prospects of the Halal Hotel Industry in Muslim-majority and Muslim-minority Countries: The Case of Malaysia and Thailand. Journal of Halal Industry and Services, 1(1).

Widagdyo, K. G., 2015. Analisis Pasar Pariwisata Halal Indonesia. The Journal of Tauhidinomics, 1(1), pp. 73-80.

Wong, K. M., Velasamy, P. \& Arshad, T. N. T., 2014. Medical Tourism Destination SWOT Analysis: A Case Study of Malaysia, Thailand, Singapore and India. s.l., EDP Sciences.

Yusof, S. M. \& Shutto, N., 2014. The Development of Halal Food Market in Japan: An Exploratory Study. Kuala Lumpur, Procedia — Social and Behavioral Sciences, pp. 253-261. 